\title{
ORIGINAL
}

ARTICLES

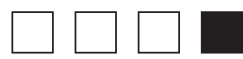

\section{The Impact of Oral Health Training for Primary Care Clinicians: A Systematic Review}

Kathleen Dwiel, MSPH; Martell A. Hesketh; Jessica L. Alpert; Jacqueline Cellini, MLIS, MPH; Kristen Goodell, MD; Russell S. Phillips, MD; Erin E. Sullivan, PhD

BACKGROUND AND OBJECTIVES: Despite recent improvements in access to health care, many Americans still lack access to dental care. There has been a national focus on interprofessional education and team-based care to work toward the integration of services including dental care into primary care. The purpose of this systematic review is to understand the impact of implementing oral health curricula in primary care training on measurable changes in primary care practice.

METHODS: Researchers utilized a two-step process, first a scoping review and then using the PRISMA systematic review method to develop inclusion and exclusion criteria around audience, curricula, and outcomes to identify practice change due to oral health education curricula delivered in primary care clinician training. Researchers assessed titles, abstracts, and full texts and abstracted data for the review.

RESULTS: Researchers reviewed 2,749 articles and found 12 meeting the systematic review criteria. The reported outcomes and evaluations differed for each of the 12 studies identified. Over $40 \%$ utilized self-reporting. Seven of the included studies tracked outcomes by checklists embedded in electronic health records changes to well-child visit forms, or chart audits, one of which also tracked billing reimbursements.

CONCLUSIONS: Oral health curricula for primary care clinicians are too heterogeneous to determine the effects on practice behavior. Future research should focus on developing a clear evaluation framework for measuring practice level changes in primary care settings as a result of implementing an oral health curriculum.

(Fam Med. 2019;51(3):251-61.)

doi: 10.22454/FamMed.2019.232634

$\mathbf{T}$ he historical separation between the oral and medical health care systems in the United States has had an adverse effect on the health of millions of Americans. About one-third of the US population faces barriers to accessing dental care, especially children and racial and ethnic minorities. ${ }^{1}$ Since the surgeon general's landmark publication, Oral Health in America, the importance of cross-disciplinary competence in oral health among health care clinicians has been increasingly recognized. ${ }^{2}$ Since this publication, there has been a national focus on interprofessional education and team-based care to work toward the integration of services, including dental care, into primary care. ${ }^{3,4}$ With increased integration, clinicians can more effectively work toward achieving the triple aim: improving the health of the population, enhancing the patient experience and outcomes, and reducing cost. Current examples of oral health and primary care integration include adding interprofessional experiences in medical, physician assistant (PA), nurse practitioner (NP), and dental schools ${ }^{4}$; imbedding dentists in federally qualified health centers to assist with dental referrals ${ }^{5}$; and offering oral health screenings at primary care offices and fluoride varnish in pediatric practice ${ }^{6}$ Conversely, some dental offices have even begun offering primary care services like blood pressure monitoring. ${ }^{7}$ Even with current barriers to health care, more people have access to a primary care clinician than a dentist, and primary care clinicians have the scope of practice necessary to provide basic dental interventions and screening. So researchers focused this review on integrating oral health training into primary care, which increases the quality of care patients receive

From Harvard Medical School Center for Primary Care (Drs Phillips and Sullivan, and Mss Dwiel, Alpert, and Hesketh); Countway Library of Medicine, Boston, MA (Ms Cellini); and Boston University School of Medicine (Dr Goodell). 
and improves access to oral health services.

\section{Oral Health Training}

A necessary step in integrating oral health into primary care settings is delivering training to primary care clinicians, including residents and students. One opportunity is to train clinicians while in school, but currently this training is inconsistent. In a national survey of US medical schools, $69 \%$ report offering fewer than 5 hours of oral health instruction, and $10 \%$ offer no curriculum. ${ }^{8}$ Another study surveying PA programs found that $82.5 \%$ of 142 programs were either most likely to teach or already teaching students how to examine children's teeth for cavities. ${ }^{9}$ Training also takes place in practices through CME programs, though this has not been systematically implemented in practices. It is often integrated into a practice at the urging of a champion in that practice. $^{10}$

For a well-informed curriculum either in a formal education program or as part of a practices' training focus, program implementers need to understand what educators currently know about oral health curricula. Critical questions include the nature of oral health curricula-what kind of educational program is the most effective at producing meaningful changes in practice? When should such programming occur? How long should it be; how much will it cost; and to whom should efforts be targeted? That is why this systematic review focuses on how implementing oral health curricula in primary care training impacts measurable changes in primary care practice.

\section{Methods}

This systematic review was conducted according to the guidelines outlined by the Preferred Reporting Items for Systematic Review and Meta-Analysis (PRISMA) methodology. ${ }^{11}$ The authors used a twostep process, first reviewing and describing the literature and then developing inclusion and exclusion criteria to identify practice change due to oral health education curricula applied in primary care clinician training. Researchers registered the review on PROSPERO, an international prospective register of systematic reviews (registration number: CRD42017070216) $)^{12}$.

\section{Preliminary Literature Review}

The preliminary literature search captured existing literature related to oral health curricula for primary care clinicians. The search strategy, developed in consultation with and executed by a medical librarian, utilized the following databases: PubMed, Web of Science, Embase, and several EBSCO databases including, CINAHL with Full Text, Dentistry and Oral Sciences, Science Direct, InfoTrac Health Reference Center Academic, ERIC, Academic Search Premier, and the Cochrane Database of Systematic Reviews. Papers that were not published in peerreviewed journals were considered outside the scope of this systematic review and were not included.

The search identified sources containing terms pertaining to oral health curriculum, primary health care clinicians, and interdisciplinary training, including National Library of Medicine Medical Subject Heading (MeSH terms) related to oral health curriculum and primary care clinician training. The full list of terms can be found in Table 1 .

The preliminary literature review included all sources with English translations, including both US and international sources, published January 2000 through November 2016. Two researchers (M.A.H., J.L.A.) reviewed source titles using EndNote software to determine relevance to the integration of oral health in health care training or practice. If the researcher was unsure, final determination was decided by a consensus of two researchers (M.A.H., J.L.A.) or brought to a third researcher (E.S.).

Following the title screen, researchers (M.A.H., J.L.A.) applied inclusion criteria to all sources still included. The preliminary literature review inclusion criteria stated that abstracts must include (1) oral health education for a member of the primary care team (medical doctors, NPs, registered nurses, PAs, medical assistants, or community health workers) or trainees (including medical residents and students of undergraduate, medical, nursing and PA programs); (2) elements of teaching or curricular components; and (3) integration of oral health and primary care.

In this preliminary review, researchers found that there was variation in the evaluation of the curricula described in the 85 included sources. Forty-three percent of the included sources did not collect data to evaluate the curriculum at all. Only a small number of sources included evaluation looking at outcomes directly related to practice change or patient health. ${ }^{13-21}$ The majority of evaluations examined changes in oral health knowledge or attitude of providers through pre- and posttests. Many curricula reported increases in knowledge of oral health topics and confidence in the ability to identify common oral health issues..$^{22-26}$ Evaluations also showed an increase in positive attitudes of primary care providers regarding the importance of oral health care post curriculum. ${ }^{27,28}$ However, few of the sources explored the next level in the Kirkpatrick Hierarchy for Health Professionals' Education Evaluation Model (Figure 1), to determine if there were practice behavior changes. ${ }^{29,30}$ Researchers identified this lack of meaningful practice change measurement as a significant gap in the existing literature of oral health curriculum for primary care providers and thus used it as a focus for the systematic review.

\section{Systematic Review}

When choosing the outcomes for the systematic review, researchers used the information gleaned from the preliminary literature review and the Kirkpatrick Model. The researchers focused the systematic 
Table 1: Systematic Review MeSH Terms

\begin{tabular}{|c|c|}
\hline Database & Search Terms \\
\hline PubMed & $\begin{array}{l}\text { curriculum, curriculum/standards, curricula, competency, competencies, health education, dental, health } \\
\text { promotion, health promotion course, interprofessional education competencies, oral health competencies, } \\
\text { interprofessional oral health workforce, interprofessional movement, interprofessional, practice guidelines } \\
\text { as topic, health education, dental, oral health, dental health surveys, schools, medical, oral health/ } \\
\text { education, oral health/standards, interprofessional relations, interdisciplinary studies, education, dental, } \\
\text { education, dental, graduate, schools, dental, schools, health occupations, clinical competence, clinical } \\
\text { competence/standards, education/organization and administration, education/standards, education/trends, } \\
\text { education, intervention, program, programme, education, curriculum, curricula, tool*, toolkit, continuing } \\
\text { education, continuing ed AND obstetrics, nurse midwives, pediatrics, physicians, nurse practitioners, } \\
\text { physicians, primary care, internal medicine, obstetrics and gynecology department, hospital, osteopathic } \\
\text { physicians, students, medical AND family practice AND family nurse practitioners AND pediatric } \\
\text { nurse practitioners, physician assistants, primary care nursing, education, public health professional, } \\
\text { physician-nurse relations, primary care providers, primary health care, physical examination AND oral } \\
\text { systemic health, oral health, oral pathology, head and neck pathology, oral disease, oral condition, oral } \\
\text { and maxillofacial, orofacial, oral health, oral health, oral hygiene, oral hygiene/education, oral hygiene/ } \\
\text { organization and administration, oral hygiene/standards, oral health/organization and administration, } \\
\text { oral health/standards, oral health/trends, dental health, oral medicine, dental health, dental hygiene }\end{array}$ \\
\hline $\begin{array}{l}\text { Web of } \\
\text { Science } 1\end{array}$ & $\begin{array}{l}\text { oral health, oral care, mouth care, dental care, oral hygiene, dental hygiene, oral health care, oral status } \\
\text { AND curriculum, education, medical school, nursing, curricula, competency, competencies }\end{array}$ \\
\hline $\begin{array}{l}\text { Web of } \\
\text { Science } 2\end{array}$ & $\begin{array}{l}\text { dental health education, oral health competency, interprofessional, intervention, program, programmed, } \\
\text { education, curriculum, curricula, tool, toolkit, continuing education, continuing ed AND physicians, } \\
\text { nurse practitioners, primary care, internal medicine, osteopathy, medical students, family practice, nurse } \\
\text { practitioner, physician assistants, primary care providers, primary health care, medicine AND oral } \\
\text { systemic health, oral health, oral pathology, head AND neck pathology, oral disease, oral condition, oral } \\
\text { and maxillofacial, orofacial, dental health, oral medicine, dental health, dental hygiene }\end{array}$ \\
\hline EBSCO & $\begin{array}{l}\text { dental health education, oral health competencies, interprofessional, intervention, program, programme, } \\
\text { education, curriculum, curricula, tool, toolkit, continuing education, continuing ed AND physicians, } \\
\text { nurse practitioners, primary care, internal medicine, osteopath, medical students, family practice, nurse } \\
\text { practitioner, physician assistants, primary care providers, primary health care, medicine AND oral } \\
\text { systemic health, oral health, oral pathology, head and neck pathology, oral disease, oral condition, oral } \\
\text { and maxillofacial, orofacial, dental health, oral medicine, dental health, dental hygiene }\end{array}$ \\
\hline Embase 1 & $\begin{array}{l}\text { oral health, mouth hygiene, dental health AND primary health care, primary medical care, nurse } \\
\text { practitioner, obstetrics, gynecologic care, osteopathic medicine, pediatric, pediatrics education, nurse } \\
\text { midwife, internal medicine, physician assistant, family medicine, medical students AND clinical education, } \\
\text { medical education, physical examinations and diagnoses, curriculum development, curriculum, education } \\
\text { program, intervention, program, programme, education, curriculum, curricula, tool, toolkit, continuing } \\
\text { education, continuing ed }\end{array}$ \\
\hline Embase 2 & $\begin{array}{l}\text { oral health, mouth hygiene, dental health AND primary health care, primary medical care, nurse } \\
\text { practitioner, obstetrics, gynecologic care, osteopathic medicine, pediatric, pediatrics education, nurse } \\
\text { midwife, internal medicine, physician assistant, family medicine, medical students AND clinical } \\
\text { education, medical education, physical examinations and diagnoses, curriculum development, curriculum, } \\
\text { education program, intervention, program, programme, education, curriculum, curricula, tool, toolkit, } \\
\text { continuing education, continuing ed AND interprofessional, interprofessional education, interprofessional } \\
\text { collaboration }\end{array}$ \\
\hline Embase 3 & $\begin{array}{l}\text { oral health, mouth hygiene, oral pathology, head and neck pathology, oral disease, oral condition, oral and } \\
\text { maxillofacial, orofacial, dental health AND primary health care, primary medical care, nurse practitioner, } \\
\text { obstetrics, gynecologic care, osteopathic medicine, pediatric, pediatrics education, nurse midwife, internal } \\
\text { medicine, physician assistant, family medicine, medical students AND clinical education, medical } \\
\text { education, physical examinations and diagnoses, curriculum development, curriculum, education program }\end{array}$ \\
\hline
\end{tabular}


Figure 1: Kirkpatrick Education Evaluation Model $^{29}$

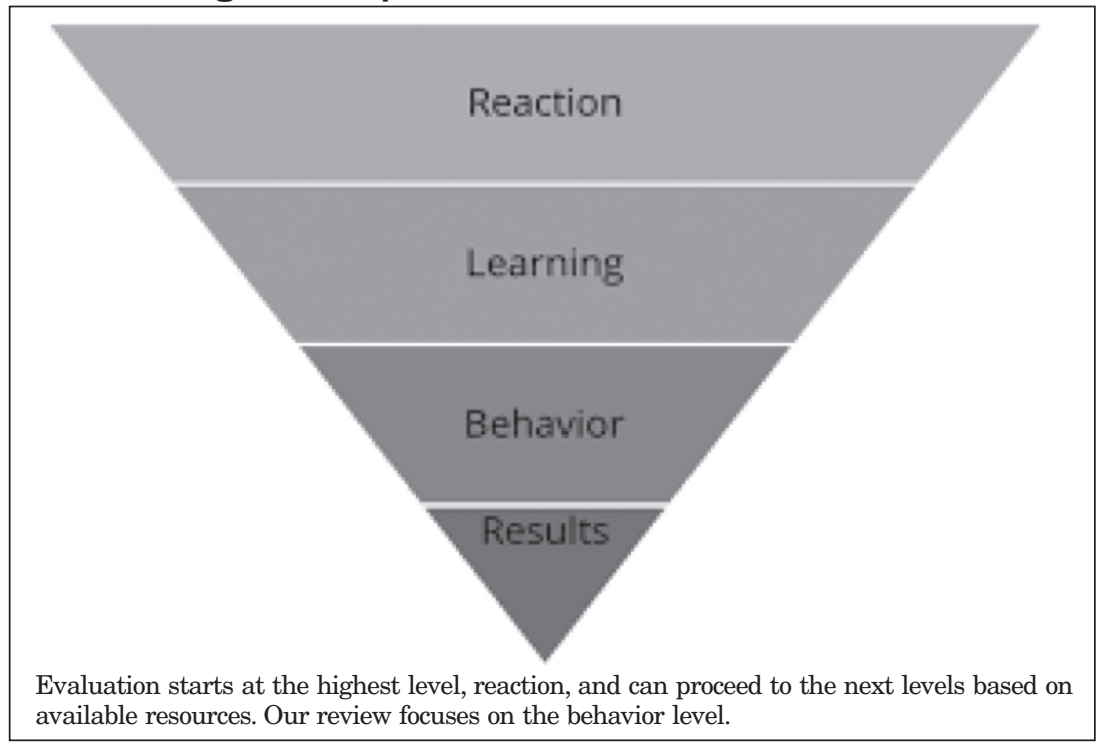

review question at the behavior level of Kirkpatrick's pyramid, looking at whether the education led to the transfer of learning to behavior change at work. Many of the studies measured attitudinal change or knowledge acquired. The reaction and learning aspects of the model, though necessary, are not sufficient for practice change to happen. The Oral Health Workforce Research Center found in their December 2016 report that $93 \%$ of PA students- $75 \%$ of whom completed oral health training as part of their program-rated integrating oral health services into clinical practice as important or very important. However, only $36 \%$ reported providing any oral health services, with the majority of those services provided for acute problems and not as part of a general exam. ${ }^{31}$ The behavior level is where we start seeing participants using what they have learned to make changes in a practice that integrates oral health into primary care, and where oral health care activities are implemented. Measuring practice change is important because clinicians face resistance from staff and colleagues when implementing interventions in primary care settings that go beyond having a curriculum (such as integrating dental procedures into practice flow). ${ }^{13}$
To begin the systematic review, the medical librarian reran the litsources through June 13, 2017. Two researchers (M.A.H., K.D.) reviewed the new sources and the previously identified sources that met the preliminary literature review criteria against the systematic review inclusion criteria. These criteria stated that the curriculum must (1) be implemented as part of primary care training (including continuing education), (2) feature oral health education in primary care training, (3) be implemented for individuals who are part of the traditional primary care team or trainees, (4) be evaluated by a measureable change in practice, and (5) be compared to "no current implemented oral health curricula." The exclusion criteria were that (1) sources could not include outcomes that measured only changes in knowledge or attitude, (2) be purely an editorial or letter, or (3) include training for anyone outside of the traditional primary care team. While the use of a control or comparison group in an evaluation can provide reliable baseline comparison data for an intervention, the authors chose not to require a comparison group in the inclusion criteria because the authors wanted to conduct the most comprehensive review erature searches to capture new possible. Most sources discussed implementing training where there had been no training before. Building on the fact that most of these were new trainings, and because information on dental care by primary care providers was rarely collected prior to implementation, pre- and postdata were not required.

One researcher (M.A.H.) extracted data from the full text of sources that met the systematic review criteria, and summarized the following information in the abstraction tool: article authors, journal name, publication year, curricular or educational component summary, curriculum target audience, type of primary care clinician involved, patient population served, curriculum implementer and location, evaluation and outcomes data, curriculum mode of delivery and duration. After reviewing the abstraction tool, the researchers added author affiliations, recruitment strategy, use of controls, how outcomes were measured, and reported limitations to have complete information needed for the review and to identify the risk of bias. Two researchers (K.D., M.A.H.) then reviewed the information extracted and finalized the entries.

\section{Results}

With the preliminary literature review, 2,548 sources were identified and all but 85 were excluded through the title and abstract screens. The updated literature search (June 2017) included an additional 201 sources. After applying systematic review criteria, the systematic review included 12 sources. Figure 2 shows the full process of source selection and exclusion based on the PRISMA framework.

\section{Qualitative Review of the \\ Literature}

There was great variety in the systematic review's 12 articles as documented in Table 2. Participants in trainings ranged from entire clinic staffs to one specific student or resident group, (eg, pediatric NP students). Additionally, the curricula 
Figure 2: Source Selection Process Using PRISMA Framework

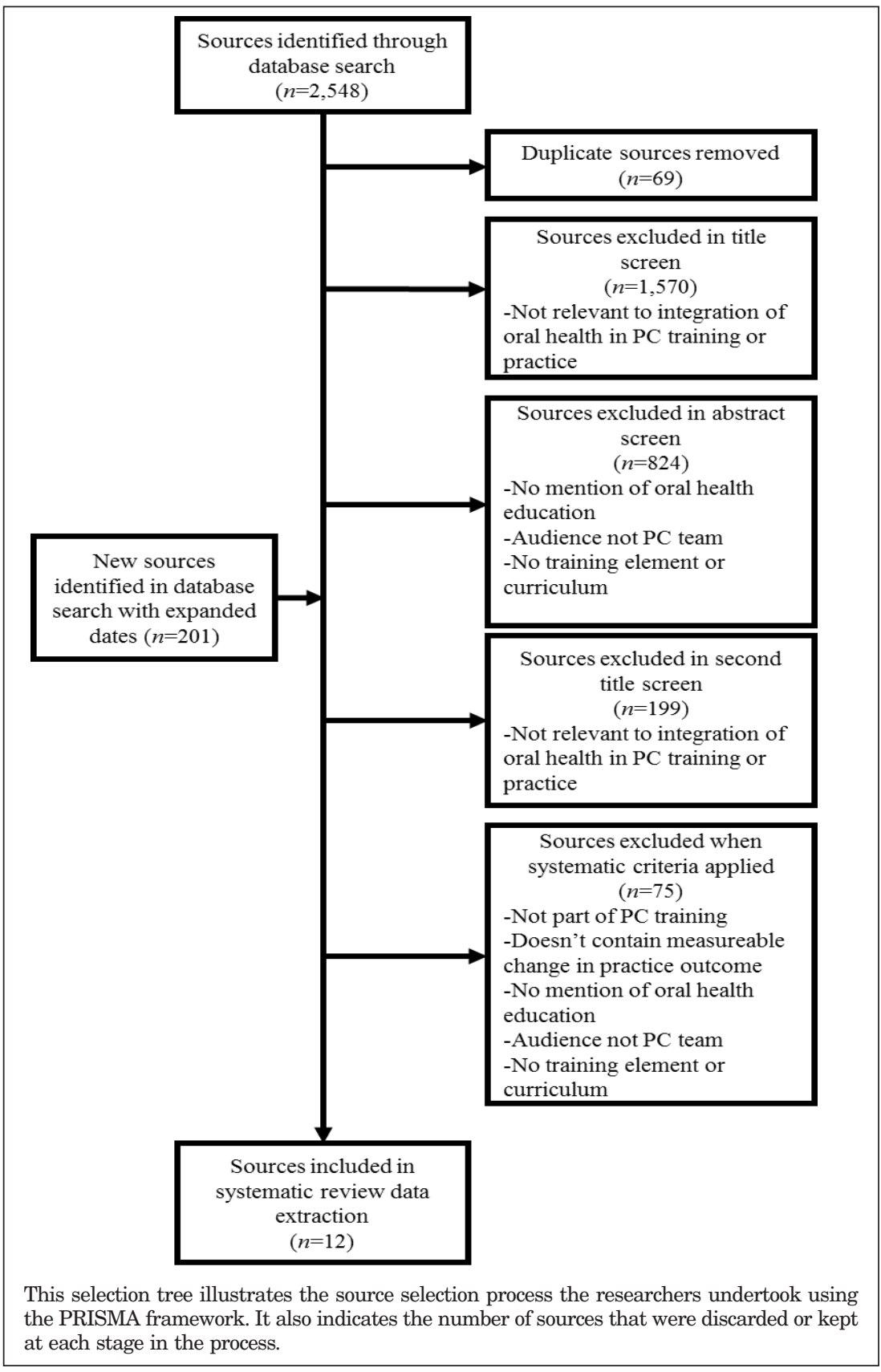

topics covered, mode of delivery, and length of training varied from two 45-minute presentations to 20 hours of training over the course of a 2-year program. Curricula were offered online and in person, and included didactic components $(\mathrm{n}=11)$, clinical training $(\mathrm{n}=6)$, small groups to discuss training materials $(\mathrm{n}=3)$, and simulations/case studies $(\mathrm{n}=3) .13,14,17,19-21,23,24,32-35$ Variation

\section{Practice Change Measures}

The evaluation method differed for each of the 12 studies identified. A notable aspect of the final set of studies is that over $40 \%$ utilized selfreporting. ${ }^{13,14,17,23,32}$ Self-reporting was often conducted through the use of posttraining surveys. These posttraining surveys asked clinicians if they had integrated oral health screenings into their wellness visits and how many times they had performed an oral health screening since receiving the training. However, not all included studies relied on self-reporting by memory to measure changes at the practice level. As seen in Figure 3, seven of the included studies tracked outcomes by checklists embedded in electronic health records (EHR), changes to well-child visit forms, or chart audits, one of which also tracked billing reimbursements. ${ }^{19-21,24,33-35}$

Practice change measures included the number of oral care procedures completed, screenings done, referrals made, fluoride varnish treatments applied, oral health education conversations had with patients, oral health problems identified, preventive oral health procedures done, and fluoride prescriptions prescribed. Some sources described exactly what measures they collected while others referred to the number of preventive oral health visits or chart documentation about oral health education. There was variation in what the outcomes were as well as in the way they were collected. All of the included sources reported a positive trend in at least one practice change measure following the delivery of their respective curriculum.

traditionally allows for analysis into necessary components for change, but the practice change outcomes and the way they were measured were also highly variable. Additionally, children's oral health was the focus of 8 of the final 12 sources with curriculum developed for pediatric clinicians or focused on dental care for children.

\section{Risk of Bias Assessment}

A risk of bias assessment looks at the likelihood that a study may have systematic error in the results or inferences. ${ }^{36}$ Seven of the studies as assessed by two reviewers (K.D., M.A.H.) had a high or unknown risk of bias. The authors included the studies despite this limitation because they highlighted the need 
Table 2: Summary of Curricula and Practice Change Outcomes

\begin{tabular}{|c|c|c|c|c|c|c|}
\hline Source & Setting & Participants & Curriculum & $\begin{array}{l}\text { Mode and Length } \\
\text { of Training }\end{array}$ & $\begin{array}{c}\text { Practice Change } \\
\text { Outcome }\end{array}$ & $\begin{array}{c}\text { Risk of } \\
\text { Bias }\end{array}$ \\
\hline $\begin{array}{l}\text { Anderson } \\
\text { KL, Smith } \\
\text { BS, Brown G. } \\
2013 .^{17}\end{array}$ & $\begin{array}{l}\text { PA school } \\
\text { and PAs } \\
\text { working in } \\
\text { clinics }\end{array}$ & $\begin{array}{l}23 \text { graduates } \\
\text { from a PA } \\
\text { program }\end{array}$ & $\begin{array}{l}\text { Included the } \\
\text { integration of the } \\
\text { established PA head } \\
\text { and neck exam with } \\
\text { intraoral evaluation, } \\
\text { oral evaluation, } \\
\text { caries prevention, } \\
\text { fluoride therapy, oral } \\
\text { habits, oral cancer } \\
\text { and pathology, tooth } \\
\text { development, and } \\
\text { systemic/oral health } \\
\text { relationships. }\end{array}$ & $\begin{array}{l}\text { Didactic training } \\
\text { (number and } \\
\text { length of sessions } \\
\text { not mentioned). }\end{array}$ & $\begin{array}{l}\text { Generalist } \\
\text { PAs performed } \\
\text { significantly more oral } \\
\text { care procedures than } \\
\text { specialist PAs. } \\
\text { Generalist PAs also } \\
\text { observed significantly } \\
\text { more oral health } \\
\text { problems (eg, rampant } \\
\text { dental caries, risk } \\
\text { factors for caries). }\end{array}$ & 赵 \\
\hline $\begin{array}{l}\text { Bowser J, } \\
\text { Sivahop J, } \\
\text { Glicken A. } \\
2013 .^{23}\end{array}$ & $\begin{array}{l}\text { PA } \\
\text { program } \\
\text { at the } \\
\text { University } \\
\text { of Colorado }\end{array}$ & $\begin{array}{l}40 \mathrm{PA} \\
\text { students }\end{array}$ & $\begin{array}{l}\text { Included etiology and } \\
\text { prevention, pathology, } \\
\text { mouth exams, } \\
\text { fluoride varnishing, } \\
\text { recognition and } \\
\text { treatment or common } \\
\text { oral health issues, } \\
\text { and billing. }\end{array}$ & $\begin{array}{l}\text { Spanned } 3 \\
\text { academic years. } \\
4 \text { hours of } \\
\text { training per year } \\
\text { including didactic } \\
\text { lectures and } \\
\text { hands on lab time. }\end{array}$ & $\begin{array}{l}\text { Students reported } 279 \\
\text { oral health procedures } \\
\text { performed in their } \\
\text { third year: } \\
45 \text { screening } \\
23 \text { varnish } \\
82 \text { education } \\
42 \text { referral. }\end{array}$ & 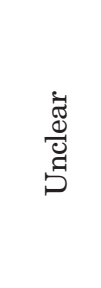 \\
\hline $\begin{array}{l}\text { Close K, Rozier } \\
\text { G R, Zeldin } \\
\text { LP, Gilbert AR. } \\
2010 .^{13}\end{array}$ & $\begin{array}{l}\text { Pediatric } \\
\text { and family } \\
\text { medicine } \\
\text { practices } \\
\text { in North } \\
\text { Carolina }\end{array}$ & $\begin{array}{l}77 \text { practices; } \\
231 \text { medical } \\
\text { providers }\end{array}$ & $\begin{array}{l}\text { Included screening, } \\
\text { parental counseling, } \\
\text { fluoride varnishing, } \\
\text { risk assessments, and } \\
\text { protocols. }\end{array}$ & $\begin{array}{l}\text { There were three } \\
\text { groups: } \\
\text { Group 1: } 2 \text { hours } \\
\text { didactic training. } \\
\text { Group 2: Group } \\
\text { 1+ a learning } \\
\text { collaborative. } \\
\text { Group 3: } \\
\text { Group } 2+\text { in- } \\
\text { office technical } \\
\text { assistance. }\end{array}$ & $\begin{array}{l}70.3 \% \text { of participants } \\
\text { were providing dental } \\
\text { services on a routine } \\
\text { basis. }\end{array}$ & 㺃 \\
\hline $\begin{array}{l}\text { Douglass JM, } \\
\text { Douglass, AB, } \\
\text { Silk H. } 2005 .{ }^{14}\end{array}$ & $\begin{array}{l}\text { Family } \\
\text { medicine } \\
\text { and } \\
\text { pediatric } \\
\text { residency } \\
\text { programs } \\
\text { in } \\
\text { Connecticut }\end{array}$ & $\begin{array}{l}245 \\
\text { participants }\end{array}$ & $\begin{array}{l}\text { Included infant } \\
\text { oral health, early } \\
\text { childhood caries } \\
\text { prevalence, etiology, } \\
\text { prevention, fluoride } \\
\text { prescribing. }\end{array}$ & $\begin{array}{l}\text { In person or } \\
\text { online 1-hour } \\
\text { slide presentation. } \\
\text { In person or } \\
\text { online } 1 \text { hour case } \\
\text { based learning } \\
\text { exercises. } \\
\text { A pocket-sized } \\
\text { handout. }\end{array}$ & $\begin{array}{l}\text { Increase from } 28 \% \text { of } \\
\text { clinicians at baseline } \\
\text { referring children to } \\
\text { the dentist at age one, } \\
\text { compared to } 73 \% \text {. } \\
\text { Increase explain to } \\
\text { parents how to brush } \\
\text { child's teeth from } 31 \% \\
\text { to } 56 \% \text {. }\end{array}$ & 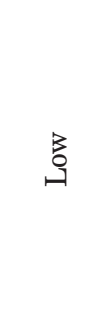 \\
\hline $\begin{array}{l}\text { Golinveaux } \\
\text { J, Gerbert B, } \\
\text { Cheng J, et al. } \\
2013 .{ }^{32}\end{array}$ & $\begin{array}{l}\text { Pediatric } \\
\text { NP } \\
\text { program at } \\
\text { UCSF }\end{array}$ & $\begin{array}{l}31 \text { first-year } \\
\text { students }\end{array}$ & $\begin{array}{l}\text { Included the } \\
\text { First Smiles and } \\
\text { AAP curriculum, } \\
\text { examining children } \\
\text { and applying fluoride } \\
\text { varnish. }\end{array}$ & $\begin{array}{l}\text { 1-hour lecture } \\
\text { 1-hour skills } \\
\text { simulation } \\
\text { exercise } \\
\text { half-day } \\
\text { observation } \\
\text { session at the } \\
\text { UCSF Pediatric } \\
\text { Dentistry Clinic. }\end{array}$ & $\begin{array}{l}83 \% \text { of the subjects } \\
\text { reported having } \\
\text { incorporated oral } \\
\text { examinations into } \\
\text { their well-child visits. }\end{array}$ & 丞 \\
\hline
\end{tabular}


Table 2, continued

\begin{tabular}{|c|c|c|c|c|c|c|}
\hline Source & Setting & Participants & Curriculum & $\begin{array}{l}\text { Mode and Length } \\
\text { of Training }\end{array}$ & $\begin{array}{l}\text { Practice Change } \\
\text { Outcome* }\end{array}$ & $\begin{array}{l}\text { Risk of } \\
\text { Bias }\end{array}$ \\
\hline $\begin{array}{l}\text { Gonsalves } \\
\text { WC, Skelton } \\
\text { J, Smith T, } \\
\text { Hardison D, } \\
\text { Ferretti G. } \\
2004 .^{33}\end{array}$ & $\begin{array}{l}\text { UK and } \\
\text { Pikeville } \\
\text { osteo-pathic } \\
\text { residency } \\
\text { programs }\end{array}$ & 23 residents & $\begin{array}{l}\text { The Physician's' Oral } \\
\text { Health Education in } \\
\text { Kentucky Curriculum } \\
\text { and included oral } \\
\text { exams and fluoride } \\
\text { varnishes }\end{array}$ & $\begin{array}{l}\text { 16-hour didactic } \\
\text { lectures. } \\
\text { 4-hour clinical } \\
\text { experience in a } \\
\text { dental practice } \\
\text { setting. }\end{array}$ & $\begin{array}{l}65.6 \% \text { checked the } \\
\text { screening examination } \\
\text { boxes completely. } \\
8 \% \text { percent indicated } \\
\text { that counseling and } \\
\text { referral had occurred. } \\
5 \% \text { noted disease } \\
\text { (thrush) present in } \\
\text { the mouth and treated } \\
\text { correctly. }\end{array}$ & 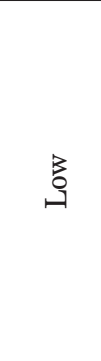 \\
\hline $\begin{array}{l}\text { Graham E, } \\
\text { Negron R, } \\
\text { Domoto P, } \\
\text { Milgrom P. } \\
2003 .{ }^{19}\end{array}$ & $\begin{array}{l}\text { A primary } \\
\text { care } \\
\text { teaching } \\
\text { clinic that } \\
\text { serves } \\
\text { a low- } \\
\text { income and } \\
\text { multiethnic } \\
\text { population }\end{array}$ & $\begin{array}{l}\text { Included } \\
\text { personnel } \\
\text { from a single } \\
\text { clinic, no } \\
\text { number of } \\
\text { participants } \\
\text { given }\end{array}$ & $\begin{array}{l}\text { Focused on children's } \\
\text { dental health includes } \\
\text { pathogenesis of caries, } \\
\text { preventive measures, } \\
\text { oral examinations } \\
\text { applying fluoride } \\
\text { varnish and referral } \\
\text { forms. }\end{array}$ & $\begin{array}{l}\text { Two 45-minute } \\
\text { didactic teaching } \\
\text { sessions. } \\
\text { Additional } \\
\text { training is given } \\
\text { each year for new } \\
\text { staff and pediatric } \\
\text { residents. }\end{array}$ & $\begin{array}{l}\text { Dental caries became } \\
\text { the eleventh most } \\
\text { common diagnosis } \\
\text { seen in the clinic from } \\
\text { not appearing in the } \\
\text { top } 40 \text {. } \\
\text { Fluoride varnish } \\
\text { applications were } \\
\text { documented in the } \\
\text { billing system on } 131 \\
\text { occasions. }\end{array}$ & 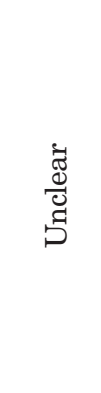 \\
\hline $\begin{array}{l}\text { Grant J S, } \\
\text { Roberts M W, } \\
\text { Brown WD, } \\
\text { Quinoñez RB. } \\
2007 .^{35}\end{array}$ & $\begin{array}{l}\text { North } \\
\text { Carolina } \\
\text { Children's } \\
\text { hospital, } \\
\text { pediatric } \\
\text { medical } \\
\text { residents }\end{array}$ & $\begin{array}{l}\text { Number of } \\
\text { participants } \\
\text { not reported }\end{array}$ & $\begin{array}{l}\text { Into the Mouths of } \\
\text { Babes Varnish and } \\
\text { Screening Program } \\
\text { (no detail on } \\
\text { curriculum elements) }\end{array}$ & $\begin{array}{l}\text { No details on } \\
\text { mode or length } \\
\text { reported }\end{array}$ & $\begin{array}{l}73 \% \text { of all eligible } \\
\text { children received a } \\
\text { preventive oral health } \\
\text { service. } \\
88 \% \text { of program } \\
\text { eligible children } \\
\text { received oral health } \\
\text { education and fluoride } \\
\text { varnish. } \\
14.1 \% \text { of children were } \\
\text { referred to a dentist. }\end{array}$ & 密 \\
\hline $\begin{array}{l}\text { Lopreiato J O, } \\
\text { Foulds DM, } \\
\text { Littlefield J H. } \\
2000 .^{34}\end{array}$ & $\begin{array}{l}\text { Pediatric } \\
\text { training } \\
\text { program } \\
\text { of the } \\
\text { University } \\
\text { of Texas } \\
\text { Health } \\
\text { Science } \\
\text { Center San } \\
\text { Antonio }\end{array}$ & $\begin{array}{l}66 \text { residents } \\
\text { of pediatric } \\
\text { training } \\
\text { program }\end{array}$ & Not described & $\begin{array}{l}\text { Spanned } 2 \\
\text { academic years. } \\
\text { A module that } \\
\text { included goals and } \\
\text { objectives, a list } \\
\text { of specific reading } \\
\text { assignments from } \\
\text { the pediatric } \\
\text { literature, a } \\
\text { self-assessment } \\
\text { quiz, and a case } \\
\text { scenario. } \\
\text { A meeting with a } \\
\text { faculty member } \\
\text { in small groups } \\
\text { before the start } \\
\text { of their weekly } \\
\text { continuity clinics. }\end{array}$ & $\begin{array}{l}\text { The percentage of } \\
\text { charts that recorded } \\
\text { a tooth examination } \\
\text { was } 57.3 \% \text { in } 1^{\text {st }} \text { year } \\
\text { control residents and } \\
100 \% \text { in the } 1^{\text {st }} \text { year } \\
\text { study group; } 53.1 \% \\
\text { in } 2^{\text {nd }} \text { year controls } \\
\text { and } 93.9 \% \text { in } 2^{\text {nd }} \text { year } \\
\text { study group. } \\
\text { Fluoride given was } \\
56 \% \text { in } 1^{\text {st }} \text { year } \\
\text { controls and } 82.9 \% \\
\text { in } 1^{\text {st }} \text { year study } \\
\text { group. No significant } \\
\text { difference for } 2^{\text {nd }} \\
\text { years. } \\
\text { No significant } \\
\text { improvements } \\
\text { in dental exams } \\
\text { or fluoride in } \\
\text { standardized patient } \\
\text { encounters. }\end{array}$ & בְּ \\
\hline
\end{tabular}


Table 2, continued

\begin{tabular}{|c|c|c|c|c|c|c|}
\hline Source & Setting & Participants & Curriculum & $\begin{array}{l}\text { Mode and Length } \\
\text { of Training }\end{array}$ & $\begin{array}{l}\text { Practice Change } \\
\text { Outcome* }\end{array}$ & $\begin{array}{c}\text { Risk of } \\
\text { Bias }\end{array}$ \\
\hline $\begin{array}{l}\text { Schaff-Blass } \\
\text { E, Rozier RG, } \\
\text { Chattopadhyay } \\
\text { A, Quiñonez R, } \\
\text { Vann Jr WF. } \\
2006 .^{24}\end{array}$ & $\begin{array}{l}\text { UNC, East } \\
\text { Carolina } \\
\text { University } \\
\text { and Wake } \\
\text { Forest } \\
\text { pediatric } \\
\text { residencies }\end{array}$ & $\begin{array}{l}143 \text { pediatric } \\
\text { residents, } 79 \\
\text { participated } \\
\text { in the } \\
\text { evaluation }\end{array}$ & $\begin{array}{l}\text { Focused on children } \\
\text { and included } \\
\text { identifying common } \\
\text { oral problems, caries } \\
\text { risk assessment, } \\
\text { indications for } \\
\text { referral; using fluoride } \\
\text { and counseling } \\
\text { caregivers regarding } \\
\text { children's oral health }\end{array}$ & $\begin{array}{l}\text { Didactic session } \\
\text { (does not specify } \\
\text { how many or } \\
\text { length). } \\
\text { Patient care } \\
\text { sessions in } \\
\text { continuity clinic. }\end{array}$ & $\begin{array}{l}96 \% \text { frequently } \\
\text { counsel parents on } \\
\text { importance of regular } \\
\text { tooth brushing. } \\
\text { Only } 5 \% \text { frequently } \\
\text { inquire about } \\
\text { caregivers' dental } \\
\text { health. } \\
\text { General preventive } \\
\text { practices are } \\
\text { performed more } \\
\text { frequently than dental } \\
\text { preventative practices. }\end{array}$ & $\begin{array}{l}\frac{c}{60} \\
.90\end{array}$ \\
\hline $\begin{array}{l}\text { Slade GD, } \\
\text { Rozier GR, } \\
\text { Zeldin LP, } \\
\text { Margolis PA. } \\
2007 . .^{20}\end{array}$ & $\begin{array}{l}\text { Private } \\
\text { pediatric } \\
\text { and family } \\
\text { physician } \\
\text { practices } \\
\text { in North } \\
\text { Carolina } \\
\text { providing } \\
\text { care to } \\
\text { children } \\
\text { with } \\
\text { Medicaid } \\
\text { aged 0-3 }\end{array}$ & $\begin{array}{l}323 \\
\text { participants } \\
(171 \\
\text { physician, } \\
152 \text { other } \\
\text { clinic } \\
\text { personnel })\end{array}$ & $\begin{array}{l}\text { Included children's } \\
\text { dental development, } \\
\text { common dental } \\
\text { diseases and their } \\
\text { prevention, screening, } \\
\text { referral, counseling } \\
\text { and fluoride varnish } \\
\text { application. }\end{array}$ & $\begin{array}{l}\text { Three } \\
\text { intervention } \\
\text { groups. } \\
\text { Group A: } 90 \\
\text { minute lecture } \\
\text { with slides, } \\
\text { case-based } \\
\text { presentations } \\
\text { and discussions } \\
\text { of the clinical } \\
\text { interventions. } \\
\text { Group B: Group } \\
\text { A+ telephone } \\
\text { conference calls } \\
\text { once every two } \\
\text { weeks. } \\
\text { Group C: Group } \\
\text { B+ in-office } \\
\text { support for } \\
\text { implementation } \\
\text { of preventive } \\
\text { dental procedures } \\
\text { provided by a } \\
\text { dental hygienist. }\end{array}$ & $\begin{array}{l}\text { Using intention-to- } \\
\text { treat analysis, rates } \\
\text { of preventive dental } \\
\text { visits did not differ } \\
\text { significantly among } \\
\text { CME groups. } \\
\text { Twenty or more } \\
\text { preventive dental } \\
\text { visits were provided } \\
\text { by } 38-49 \% \text { of practices } \\
\text { in the three study } \\
\text { groups }(P=0.64) \text {. } \\
56 \% \text { of practices } \\
\text { provided at least one } \\
\text { preventive dental } \\
\text { visit, } 43 \% \text { provided at } \\
\text { least } 20 \text { such visits, } \\
\text { and } 36 \% \text { provided at } \\
\text { least } 40 \text { such visits. } \\
\text { In the full claims } \\
\text { analysis } 63 \% \text { of } \\
\text { practices provided at } \\
\text { least one preventive } \\
\text { dental visit. }\end{array}$ & 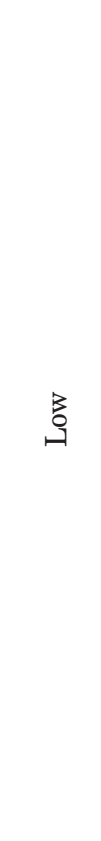 \\
\hline $\begin{array}{l}\text { Wawrzynia } \\
\text { MN, Boulter } \\
\text { S, Giotopoulos } \\
\text { C, Zivitksi J. } \\
2006 .^{21}\end{array}$ & $\begin{array}{l}\text { The Capital } \\
\text { Region } \\
\text { Family } \\
\text { Health } \\
\text { Center, a } \\
\text { training } \\
\text { center for } \\
\text { the New } \\
\text { Hamp- } \\
\text { shire- } \\
\text { Dartmouth } \\
\text { Family } \\
\text { Practice } \\
\text { Residency } \\
\text { Program }\end{array}$ & $\begin{array}{l}24 \text { family } \\
\text { practice } \\
\text { residents and } \\
10 \text { faculty }\end{array}$ & $\begin{array}{l}\text { Focused on children } \\
0-3 \text { years and } \\
\text { included early } \\
\text { childhood caries } \\
\text { prevention, oral } \\
\text { health screening, } \\
\text { applying fluoride } \\
\text { varnish during well- } \\
\text { child visits. }\end{array}$ & $\begin{array}{l}\text { Two } 1 \text { hour } \\
\text { didactic sessions } \\
\text { 1-3 one on one } \\
\text { clinical training } \\
\text { during well child } \\
\text { visits. }\end{array}$ & $\begin{array}{l}\text { Increase from } 0 \\
\text { to } 91 \% \text { for well } \\
\text { child visits with } \\
\text { documented oral } \\
\text { health screening } \\
\text { and fluoride varnish } \\
\text { application. }\end{array}$ & בְּ \\
\hline
\end{tabular}

*This column only includes practice change outcomes, though the studies may have measures other type of outcomes as well. 
Figure 3: Observed Outcomes and Measurement Tools

\begin{tabular}{|l|c|c|c|c|c|c|c|c|}
\hline & \multicolumn{2}{|c|}{ Screenings and Visits } & \multicolumn{2}{c|}{ Procedures } & \multicolumn{2}{c|}{ Referrals } \\
\hline & $\begin{array}{l}\text { Chart } \\
\text { Audit }\end{array}$ & Survey & $\begin{array}{c}\text { Billing } \\
\text { Claims }\end{array}$ & $\begin{array}{c}\text { Chart } \\
\text { Audit }\end{array}$ & Survey & $\begin{array}{c}\text { Billing } \\
\text { Claims }\end{array}$ & $\begin{array}{c}\text { Chart } \\
\text { Audit }\end{array}$ & Survey \\
\hline $\begin{array}{l}\text { Anderson KL, Smith BS, Brown, G. } \\
(2013)\end{array}$ & & $\mathrm{X}$ & & & $\mathrm{X}$ & & & $\mathrm{X}$ \\
\hline $\begin{array}{l}\text { Bowser J, Sivahop J, Glicken A. } \\
(2013)\end{array}$ & $\mathrm{X}$ & & & $\mathrm{X}$ & & & $\mathrm{X}$ & \\
\hline $\begin{array}{l}\text { Close K, Rozier R, Zeldin, LP, Gilbert } \\
\text { AR. (2010) }\end{array}$ & & $\mathrm{X}$ & & & $\mathrm{X}$ & & & \\
\hline $\begin{array}{l}\text { Douglass JM, Douglass AB, Silk HJ. } \\
\text { (2005) }\end{array}$ & $\mathrm{X}$ & $\mathrm{X}$ & & & & & $\mathrm{X}$ & $\mathrm{X}$ \\
\hline $\begin{array}{l}\text { Golinveaux J, Gerbert B, Cheng J, et } \\
\text { al. (2013) }\end{array}$ & & $\mathrm{X}$ & & & $\mathrm{X}$ & & & $\mathrm{X}$ \\
\hline $\begin{array}{l}\text { Gonsalves WC, Skelton J, Smith T, et } \\
\text { al. (2004) }\end{array}$ & $\mathrm{X}$ & & & & & & $\mathrm{X}$ & \\
\hline $\begin{array}{l}\text { Graham E, Negron R, Domoto P, et } \\
\text { al. (2003) }\end{array}$ & $\mathrm{X}$ & & & & & $\mathrm{X}$ & & \\
\hline $\begin{array}{l}\text { Schaff-Blass E, Rozier RG, et al. } \\
(2006)\end{array}$ & & $\mathrm{X}$ & & & $\mathrm{X}$ & & & \\
\hline $\begin{array}{l}\text { Slade GD, Rozier GR, Zeldin LP, et } \\
\text { al. (2007) }\end{array}$ & & & $\mathrm{X}$ & & & & & \\
\hline $\begin{array}{l}\text { Wawrzyniak MN, Boulter S, et al. } \\
(2007)\end{array}$ & $\mathrm{X}$ & & & $\mathrm{X}$ & & & & \\
\hline $\begin{array}{l}\text { Grant JS, Roberts MW, BrownWD, et } \\
\text { al. (2007) }\end{array}$ & $\mathrm{X}$ & & & $\mathrm{X}$ & & & $\mathrm{X}$ & \\
\hline $\begin{array}{l}\text { Lopreiato JO, Foulds DM, Littlefield } \\
\text { JH. (2000) }\end{array}$ & $\mathrm{X}$ & & & $\mathrm{X}$ & & & & \\
\hline
\end{tabular}

This chart illustrates the outcomes measured by each of the final 12 included sources along with the measurement tools used to collect the outcome measure. The items across the top of the chart represent the outcome measured (Screenings and Visits: preventative oral health screenings, diagnoses, prescriptions; Procedures: fluoride varnish applications; Referrals: referrals to a dental care provider). The second row of the chart represents the tool used to gather the associated outcome measure.

for better methods to evaluate the efficacy of oral health training for primary care clinicians. High risk of bias was seen in a lack of comparison groups, convenience enrollment, and self-reported outcomes. In educational interventions, practices like convenience enrollment that contribute to a high risk of bias can be unavoidable. High risk of bias was also present when funders were coauthors on the papers evaluating the work. Unknown risk was seen in unclear processes for recruitment of participants and measurement of outcomes.

\section{Discussion}

This study offers a comprehensive look at the current literature on outcomes of oral health training for primary care clinicians. Understanding the state of research in this area has important implications for medical education and future evaluations of oral health curricula for primary care clinicians.

This systematic review provides medical educators with an overview of evaluated oral health curricula that have been published in peer reviewed journals. There are many editorial and opinion pieces in academic journals that discuss ideas for curriculum to integrate oral health into training for primary care clinicians, but few published sources include the implementation and evaluation of an actual curriculum, and even fewer examine changes in practice behavior. With so many sources, but so few with recorded results, it is difficult for medical educators to find rigorously evaluated curriculum they could implement with confidence. By limiting this search to oral health curricula that included evaluation of practice changes, researchers selected curricula with reported results that can begin to illuminate the components of oral health curricula that may be needed to increase access to oral health. Researchers noted the majority of sources included focused on children. This may be because both Medicaid and the Children's Health Insurance Program require comprehensive dental health benefits for children while Medicaid for adults varies in coverage of dental benefits by state. ${ }^{37,38}$

Many of the studies used selfreported data. While self-reporting 
may be a convenient way for researchers to evaluate practice behaviors, it also introduces reporting biases into the data that skew toward socially desirable answers. ${ }^{39}$ This bias suggests that respondents who complete oral health training and then self-report on organizational behavior are more likely to report results biased towards a perceived improvement, such as performing more oral health screenings. While non-self-reported measures were not subject to the same reporting bias that self-reported measurements faced, they did contain other unexamined factors. The most significant factor was the lack of comparison groups in studies that made a structural change to collect evaluation data. This included studies that added oral health screenings to EHR checklists or visit forms. ${ }^{19,20,23}$ These studies did not examine the effect of adding this item to an EHR screening independent of the oral health training. Therefore, researchers were unable to discern if changes in practice were prompted by the training or these structural changes.

Due to the variation in the evaluation of oral health training programs, in outcomes chosen, the way the outcome was measured, and even the lack of consistent reporting on the training program, it is not possible to compare program effectiveness or reliably determine if there are particular aspects of a program that could prompt changes in practice behavior. To determine the effectiveness of these curricula there is a need for a common evaluation framework. A standardized evaluation would help answer questions like who on the primary care team should be trained, and what is the most effective way to train primary care clinicians in oral health. This would also allow future researchers to compare across curricula and evaluate which components change practice behaviors to improve the oral health of their patient population.

\section{Limitations}

The systematic review results are subject to a number of limitations. First, the final set of studies often had weak study designs that lacked comparison groups and had small sample sizes, both of which can increase bias in the results. Secondly, the scope of this systematic review was limited to peer-reviewed studies that included an evaluation of the curricula. By not including grey literature (unpublished, possibly presented only) it is possible that some curricula with practice change outcomes were missed. Risk of bias was unclear in many of the studies due to vague descriptions of the studies, making results more uncertain. Finally, the heterogeneity of the included curricula and evaluation methods precluded comparing the effectiveness across programs. Researchers were unable to make determinations regarding best practices for oral health training of primary care clinicians.

\section{Conclusions}

In conclusion, the current body of literature concerning oral health curricula for primary care clinicians is too heterogeneous to determine the parameters for optimal training programs in oral health, or to anticipate the effects of such programs on practice change. However, the high level of heterogeneity observed does demonstrate a clear need for a standardized and rigorous evaluation of oral health curricula for primary care clinicians. Future curricula should be evaluated using measurable practice changes. Optimally, evaluations would be conducted using a consistent evaluation framework based on accepted oral health competencies. By allowing future educators and researchers to understand the best practices in oral health training for primary care clinicians, we can work to improve access to basic oral health care and close the gap in oral health disparities in the United States.
ACKNOWLEDGMENTS: The authors thank Christine Riedy, PhD, MPH; Hugh Silk, MD, MPH; and Judy Savageau, MPH.

FINANCIAL SUPPORT : The project described was supported by grant number UH1HP29962 from the Health Resources and Services Administration (HRSA), an operating division of the US Department of Health and Human Services.

PRESENTATIONS: This research was presented as a poster for the 2018 Society of Teachers of Family Medicine Annual Meeting and the 2018 AcademyHealth Annual Research Meeting.

DISCLAIMER: The contents of this paper are solely the responsibility of the authors and do not necessarily represent the official views of the Health Resources and Services Administration or the US Department of Health and Human Services.

CORRESPONDING AUTHOR: Correspondence should be directed to: Erin E. Sullivan, 10 Shattuck St, Countway Library 2nd Floor Center for Primary Care, Boston, MA 02115. 617-432-2358. Fax: 617-432-1680. Erin_Sullivan@hms.harvard.edu.

\section{References}

1. American Dental Association. Access to Care. Action for Dental Health. http://www.ada.org/ en/public-programs/action-for-dental-health/ access-to-care. Accessed April 13, 2017.

2. US Department of Health and Human Services. Oral health in America: a report of the Surgeon General. Rockville, MD: Department of Health and Human Services, National Institute of Dental and Craniofacial Research, National Institutes of Health; 2000.

3. Institute of Medicine. Redesigning Continuing Education in the Health Professions. Washington, DC: The National Academies Press; 2010.

4. Core Competencies for Interprofessional Collaborative Practice. Report of an Expert Panel. Washington, D.C.: Interprofessional Education Collaborative; 2011.

5. Bailit H, D'Adamo J. State case studies: improving access to dental care for the underserved. J Public Health Dent. 2012;72(3):221234.

6. Wessel LA, Wolpin S, Sheen J, Krol D, Westpheling K, McDuffie-Bell P. Early childhood caries prevention: a training project for primary care providers. J Health Care Poor Underserved. 2005;16(2):244-247.

7. Berman CL, Guarino MA, Giovannoli SM. High blood pressure detection by dentists. J Am Dent Assoc. 1973;87(2):359-363.

8. Ferullo A, Silk H, Savageau JA. Teaching oral health in U.S. medical schools: results of a national survey. Acad Med. 2011;86(2):226-230.

9. Jacques PF, Snow C, Dowdle M, Riley N, Mao $\mathrm{K}$, Gonsalves WC. Oral health curricula in physician assistant programs: a survey of physician assistant program directors. J Physician Assist Educ. 2010;21(2):22-30. 
10. Harnagea H, Couturier Y, Shrivastava R, et al. Barriers and facilitators in the integration of oral health into primary care: a scoping review. BMJ Open. 2017;7(9):e016078.

11. Shamseer L, Moher D, Clarke M, et al; PRISMA-P Group. Preferred reporting items for systematic review and meta-analysis protocols (PRISMA-P) 2015: elaboration and explanation. BMJ. 2015;350(jan02 1):g7647.

12. Hesketh M, Dwiel K, Sullivan E. Alpert J, Cellini J, Goodell K, Phillips R. A systematic review of the effects of implementing oral health curricula in primary care training on measurable changes in primary care practice. PROSPERO. 2017 CRD42017070216. http://www. crd.york.ac.uk/PROSPERO/display_record. php?ID=CRD42017070216. Accessed January 17, 2019.

13. Close K, Rozier RG, Zeldin LP, Gilbert AR. Barriers to the adoption and implementation of preventive dental services in primary medical care. Pediatrics. 2010;125(3):509-517.

14. Douglass JM, Douglass AB, Silk HJ. Infant oral health education for pediatric and family practice residents. Pediatr Dent. 2005;27(4):284291.

15. Jackson JT, Quinonez RB, Kerns AK, et al. Implementing a prenatal oral health program through interprofessional collaboration. J Dent Educ. 2015;79(3):241-248.

16. Sjögren P, Kullberg E, Hoogstraate J, Johansson O, Herbst B, Forsell M. Evaluation of dental hygiene education for nursing home staff. J Adv Nurs. 2010;66(2):345-349.

17. Anderson KL, Smith BS, Brown G. Using an expanded oral health curriculum by practicing physician assistants. J Physician Assist Educ. 2013;24(3):23-26.

18. Coke L, Otten K, Staffileno B, Minarich L, Nowiszewski C. The impact of an oral hygiene education module on patient practices and nursing documentation. Clin J Oncol Nurs. 2015;19(1):75-80.

19. Graham E, Negron R, Domoto P, Milgrom P. Children's oral health in the medical curriculum: a collaborative intervention at a university-affiliated hospital. J Dent Educ. 2003;67(3):338-347.

20. Slade GD, Rozier RG, Zeldin LP, Margolis PA. Training pediatric health care providers in prevention of dental decay: results from a randomized controlled trial. BMC Health Serv Res. 2007;7(1):176-110.
21. Wawrzyniak MN, Boulter S, Giotopoulos C, Zivitski J. Incorporating caries prevention into the well-child visit in a family medicine residency. Fam Med. 2006;38(2):90-92.

22. Silk H, O'Grady Stille S, Baldor R, Joseph E. Implementation of STFM's "Smiles for Life" oral health curriculum in a medical school interclerkship. Fam Med. 2009;41(7):487-491.

23. Bowser J, Sivahop J, Glicken A. Advancing ora health in physician assistant education: evaluation of an innovative interprofessional oral health curriculum. J Physician Assist Educ. 2013;24(3):27-30.

24. Schaff-Blass E, Rozier RG, Chattopadhyay A Quiñonez R, Vann WF Jr. Effectiveness of an educational intervention in oral health for pediatric residents. Ambul Pediatr. 2006;6(3):157164.

25. Anderson KL, Smith BS, Maseman DC. Integration of an oral health curriculum into a physician assistant program. J Allied Health. 2011;40(1):19-24.

26. Kebriaei A, Rothe V, Pitner S, Balluff M, Salama F. Effectiveness of a basic training presentation on infant oral health care for pediatric medicine residents. J Clin Pediatr Dent. 2008;33(2):143-146

27. Mouradian WE, Reeves A, Kim S, et al. A new oral health elective for medical students at the University of Washington. Teach Learn Med. 2006;18(4):336-342. 1

28. Caspary G, Krol DM, Boulter S, Keels MA, Romano-Clarke G. Perceptions of oral health training and attitudes toward performing oral health screenings among graduating pediatric residents. Pediatrics. 2008;122(2):e465-e471.

29. Kirkpatrick DL. Evaluating training programmes: the four levels. San Francisco. Emeryville, CA: Berrett-Koehler; 1994.

30. Belfield C, Thomas H, Bullock A, Eynon R, Wall D. Measuring effectiveness for best evidence medical education: a discussion. Med Teach. 2001;23(2):164-170.

31. Langelier M, Surdu S, Gao J. AD G. Determinants of Oral Health Screening and Assessment in Physician Assistant Clinical Practice. Rensselaer, NY: Oral Health Workforce Research Center, Center for Health Workforce Studies, School of Public Health, SUNY Albany; 2016.
32. Golinveaux J, Gerbert B, Cheng J, et al. Oral health education for pediatric nurse practitioner students. J Dent Educ. 2013;77(5):581-590.

33. Gonsalves WC, Skelton J, Smith T, Hardison D, Ferretti G. Physicians' oral health education in Kentucky. Fam Med. 2004;36(8):544-546.

34. Lopreiato JO, Foulds DM, Littlefield JH. Does a health maintenance curriculum for pediatric residents improve performance? Pediatrics. 2000;105(4 II):966-972.

35. Grant JS, Roberts MW, Brown WD, Quinoñez $\mathrm{RB}$. Integrating dental screening and fluoride varnish application into a pediatric residency outpatient program: clinical and financial implications. J Clin Pediatr Dent. 2007;31(3):175178.

36. Higgins JP. Assessing risk of bias in included studies. In: Higgins JP, Green S, eds. Cochrane handbook for systematic reviews of interventions. Vol Version 5.1.0: The Cochrane Collaboration. 2011.

37. Kaiser Commission on Medicaid and the Uninsured. Oral Health and Low-Income Nonelderly Adults. A Review of Coverage and Access. Washington, DC: Henry J Kaiser Family Foundation; 2012.

38. US Department of Health and Human Services. Keep Kids Smiling: Promoting Oral Health Through the Medicaid Benefit for Children \& Adolescents. Washington, DC: Centers for Medicare and Medicaid Services; 2013.

39. Moorman RH, Podsakoff PM. A meta-analytic review and empirical test of the potential confounding effects of social desirability response sets in organizational behaviour research. J Occup Organ Psychol. 1992;65(2):131-149. 